\title{
STUDIES ON DUODENAL REGURGITATION. I
}

\author{
By GRACE MEDES AND C. B. WRIGHT \\ (From the Medical Service of the University Hospital, Minneapolis, Mrinnesota)
}

(Received for publication August 13, 1928)

\section{INTRODUCTION}

In a paper by Berglund, Wahlquist and Sherwood (1927) the authors have demonstrated the fact, originally brought out by Pavloff (1910) that the acidity of gastric juice is constant and around half of one per cent of $\mathrm{HCl}$. They have further discussed two of the possible factors affecting this acidity, the neutralization of the acid by combining with protein, or its neutralization with alkaline duodenal content. It has been our purpose in this paper to investigate the part played by duodenal regurgitation.

Some of the earliest observations of the gastric content refer to the presence of bile in the stomach. Beaumont (1838), in his celebrated work on the physiology of digestion states that bile is seldom found in the stomach, and then only under two special conditions-the first under the administration of oil or fatty foods, and the second, under mechanical irritation of the pyloric extremity. Beaumont quotes a passage from Magendie in which the latter infers that in a healthy state bile is always to be found in the stomach. Schittenhelm (1903) observed trypsin in the gastric content of patients, and suggested that it was a pathological process.

Boldyreff (1904) observed the same phenomena in dogs and suggested that the pancreatic ferments present may exert important digestive functions in the stomach. He found regurgitation to occur with such regularity that he believed it a normal process and elaborated a theory of its function in neutralizing gastric acidity. Following his work, several groups of investigators have added numerous observations supporting his theory; others, however, have found regurgitation ' occurring under such widely different conditions that they have not been able to accept Boldyreff's ideas in their entirety. A more de- 
tailed consideration of this question will be taken up in this paperunder the discussion of the effects of acid on regurgitation.

PROCEDURE

In the carrying out of this investigation, two tests for the presence of duodenal contents in the stomach were used, the appearance of bile and the presence of tryptic activity.

Twenty-three examinations were made on cases as follows:

1-10-total achylia, giving no acid on fractional meals or after injection of histamine (pernicious anemia)

11-14-duodenal ulcer

15-retroperitoneal tumor

16-asthma

17-compression myelitis

18-normal

19-20-simple achylia

21-pyloric obstruction

22-gastroenterostomy

In carrying out the experiments, the contents of the fasting stomach were removed through a Rehfuss tube with the olive located in the lower part of the stomach. The stomach was then washed at 3- to 5minute intervals with small amounts of water or of the regent selected, and samples immediately withdrawn; or the reagent was allowed to remain in the stomach and portions fractioned out at 5- to 10-minute intervals. The samples obtained were examined for bile, and tested for the presence of trypsin.

\section{Test for trypsin}

Principle. . The samples of gastric content are mixed with purified egg albumin, incubated for 48 hours at $37^{\circ}$, when the digestion mixture is tested quantitatively for free amino groups.

Procedure. About $15 \mathrm{cc}$. of each sample of gastric content are shaken with permutit to remove ammonia and filtered or centrifuged. A few cubic centimeters of the clear liquid obtained should be tested with Nessler's reagent to determine if the ammonia has been completely removed. If not, it should be shaken again with permutit and refiltered. 
Five cubic centimeters are pipetted into a centrifuge tube, and mixed with $1 \mathrm{cc}$. of a 0.1 per cent egg albumin solution. One drop of phenolphthalein is added and $0.5 \mathrm{~N}$ HCluntil the solution is acid to the phenolphthalein. Dilute $\mathrm{Na}_{2} \mathrm{CO}_{3}$ (about 10 per cent) is now dropped in until the pink just reappears. Each solution is covered with a layer of toluol and the tubes stoppered and kept in a constant temperature incubator for 24 to 48 hours.

At the end of this time the tubes are removed and the undigested protein is coagulated by adding $1 \mathrm{cc}$. of 50 per cent trichloracetic acid and heated at $90^{\circ}$ until coagulation is complete (usually about 10 minutes). The samples are then centrifuged for 15 to 30 minutes at about 3000 revolutions per minute. The clear supernatant liquid is poured off into calibrated tubes and $\mathrm{NaOH}$ and $\mathrm{Na}_{2} \mathrm{CO}_{3}$ added to bring the color back to pink.

The samples are then made up to $20 \mathrm{cc}$. and $1 \mathrm{cc}$. of 0.2 per cent Folin's amino acid reagent $(1,2,4$ naptho-quinone sodium sulphonate) added. The samples are placed in a dark closet for one hour after which $1 \mathrm{cc}$. of aceto-acetic acid and $1 \mathrm{cc}$. of sodium thiosulphate are added as directed by Folin (1925) and a color comparison made. Purified egg albumin and any test meal employed are treated similarly throughout, except that no digestive fluid is added. These are used as blanks.

\section{Preparation of egg albumin}

To the whites of three eggs (about $90 \mathrm{cc}$.) are added 60 grams anhydrous $\mathrm{Na}_{2} \mathrm{SO}_{4}$ and the volume made up to $300 \mathrm{cc}$. After standing for 3 hours in an incubator at $37^{\circ}$ to salt out the globulin, the solution is filtered and the albumin precipitated with one-tenth of its volume of 50 per cent trichloracetic acid. The solution is then poured into large centrifuge tubes and heated to $100^{\circ}$ in a water bath. The tubes are centrifuged for about one-half hour, the supernatant liquid is poured off and the precipitate of albumin stirred up in 4 per cent trichloracetic acid. This is reheated and centrifuged, and the process repeated until the supernatant liquid gives a negative test with Nessler's reagent. The final washing should be with distilled water. 'The albumin is spread on filter paper to dry and may then be pulverized. To prepare it for use, a weighted amount of the dry,.powdered albumin is dissolved 
in a graduated test tube in as small an amount as possible of 10 per cent $\mathrm{NaOH}$ and water added to make up the desired volume.

\section{EXPERIMENTS}

The first 10 experiments were on cases of pernicious anemia. The first of these is represented in figure 1 . The fasting contents were removed and the stomach washed 10 times with $250 \mathrm{cc}$. of water at $37^{\circ}$ and completely emptied after each washing. Another $250 \mathrm{cc}$. were

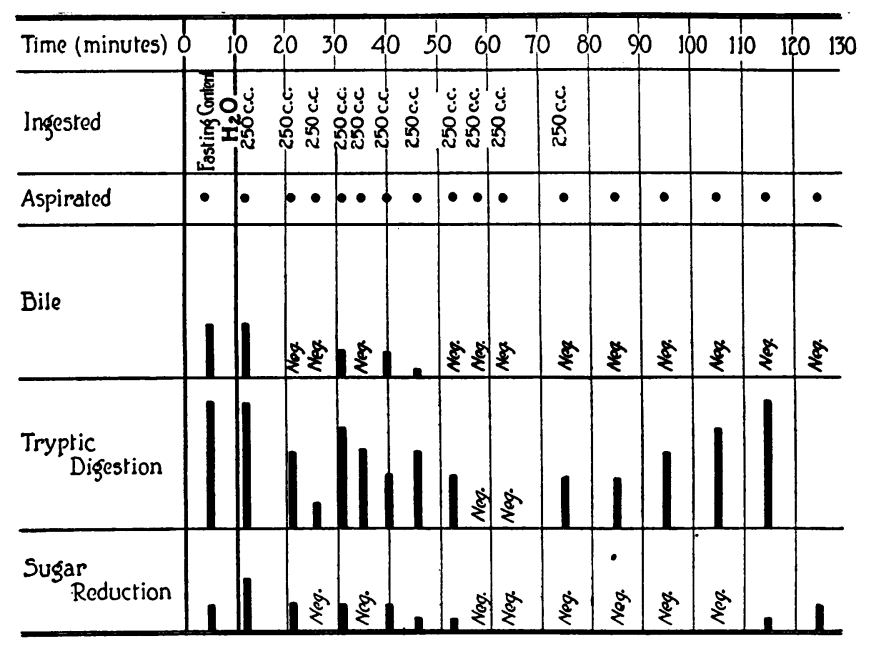

Fig. 1. (Experment 1.) Shows the Presence in the Stomach of Trypsin During Repeated Washings with Water, eVEn IN THE AbSENCE of BIIE

Note the increase in trypsin as the stomach empties

Subject: Wm. F. Diagnosis: Pernicious anemia. Date: January 22, 1927.

then introduced and samples removed at once and after 10 minute intervals for fifty minutes. Three tests were employed for duodenal regurgitation, - the presence of bile, tryptic activity, and the inversion of sucrose. The last names was tested for by incubating a few cubic centimeters of each sample with a solution of cane sugar and the solution tested, after four hours, with Benedict's reagent for reducing substances.

As may be seen from figure 1 all three tests were positive on the 


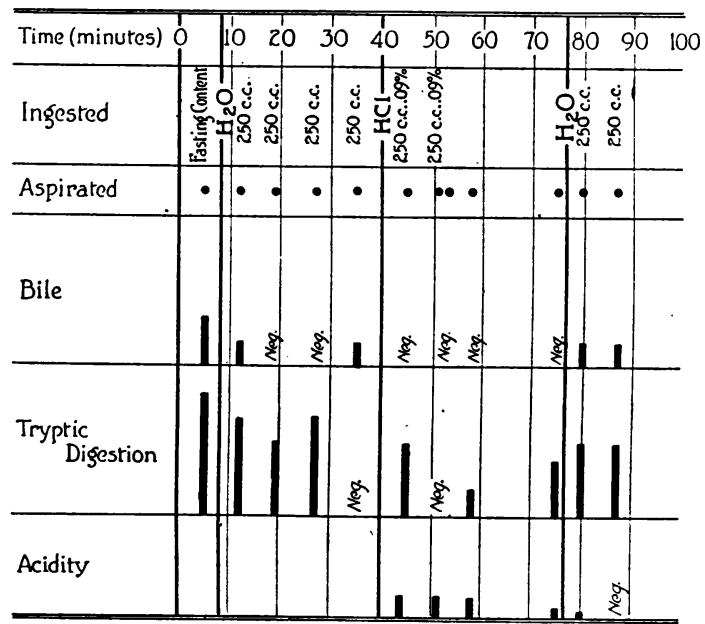

Fig. 2. (Experiment 2.) Shows the Presence in the Stomach of Trypsin DURING WashINGS with Water

Trypsin decreases with dilute acid, increases with water Subject: Carrie W. Diagnosis: Pernicious anemia. Date: January 29, 1927.

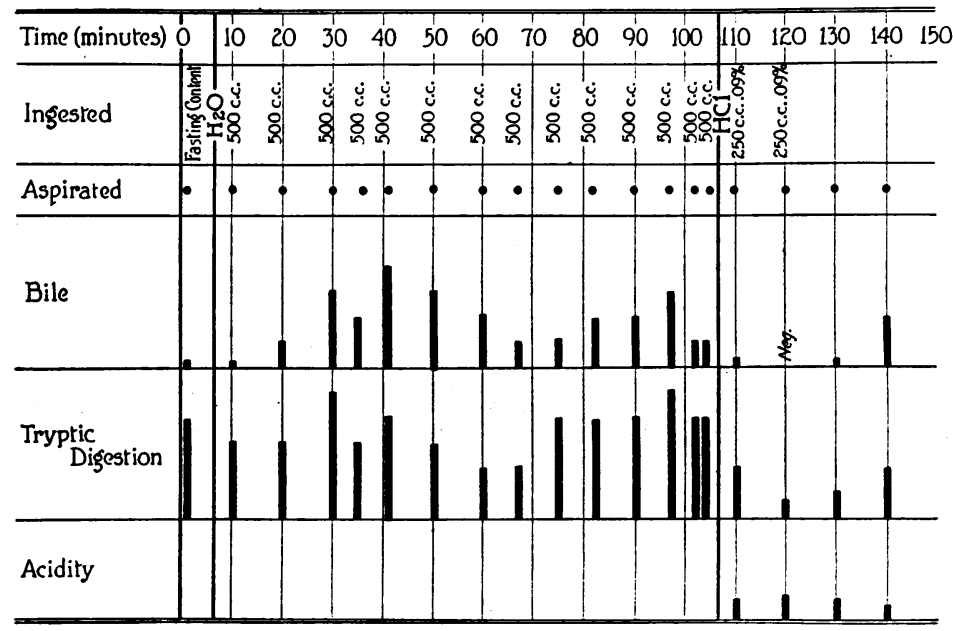

Fig. 3. (Experiment 3.) Shows the Presence in the Stomach of an Extreme Amount of Bite and Trypsin During Washings with

Water, Marked Decrease of Trypsin with Dilute AcI Subject: Nels E. Diagnosis: Pernicious anemia. Date: February 23, 1927. 


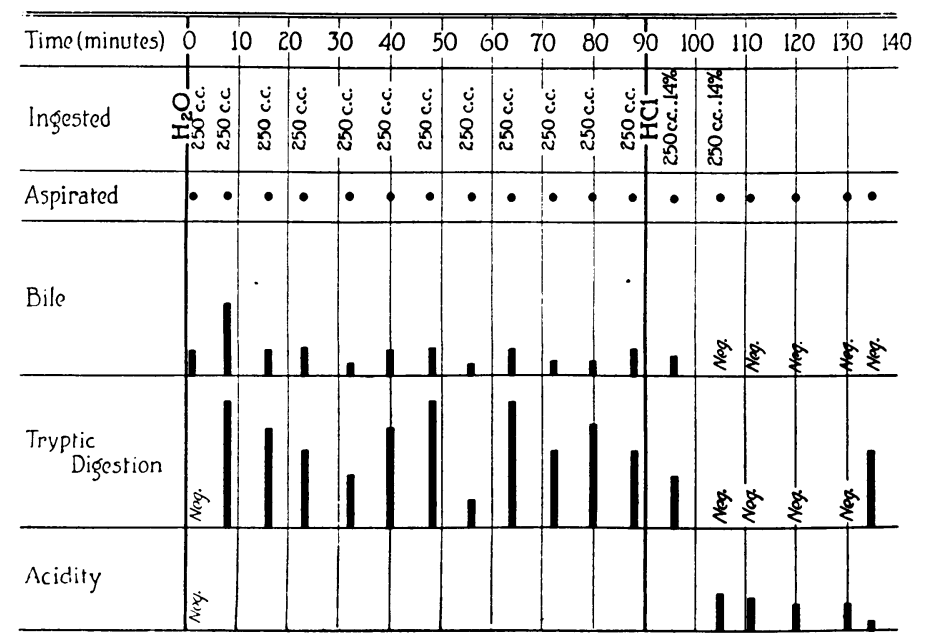

Fig. 4. (Experiment 4.) Shows the Continuous Presence in the Stomach of Bile and Trypsin During Washings with Water, the Absence of Both with Dilute Acid

Subject: Wm. F. Diagnosis: Pernicious anemia. Date: January 27, 1927.

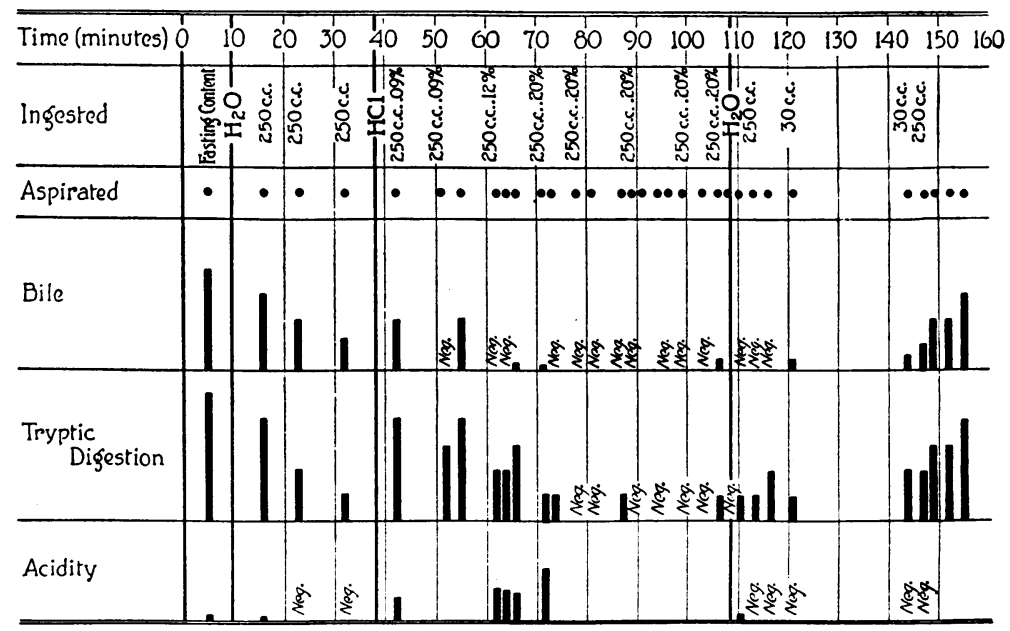

Fig. 5. (Experment 5.) Shows the Presence in the Stomach of Bine and Trypsin During Washings with Water and Dilute Acid, Their Complete Disappearance During Washings With More Concentrated ACID

Subject: Wm. F. Diagnosis: Pernicious anemia. Date: February 5, 1927. 
fasting content and the first washing. After this, bile and sucrose appeared only intermittently during the next few washings and finally disappeared entirely. As the stomach gradually became emptied upon the fractional removal of the last $250 \mathrm{cc}$. of water, sucrose reappeared. Trypsin was present in all samples except two. During the repeated washing it gradually decreased in amount, and increased during the fractional withdrawal of the water meal. Only two washings were completely negative. These results indicate that the pyloric

TABLE 1

Regurgitation in pernicious anemia. Shows the number of aspirations examined for both bile and trypsin and the number positive for each

\begin{tabular}{|c|c|c|c|c|c|c|c|c|c|c|c|c|c|c|c|c|c|c|c|}
\hline \multirow[b]{2}{*}{$\begin{array}{c}\text { Experi- } \\
\text { ment } \\
\text { number }\end{array}$} & \multicolumn{2}{|c|}{$\begin{array}{l}\text { Fasting } \\
\text { contents }\end{array}$} & \multicolumn{3}{|c|}{$\mathrm{H}_{2} \mathrm{O}$} & \multicolumn{3}{|c|}{$\begin{array}{c}\mathrm{HCl}, 0.09 \\
\text { per cent }\end{array}$} & \multicolumn{3}{|c|}{$\begin{array}{c}\mathrm{HCl}, 0.14 \\
\text { per cent }\end{array}$} & \multicolumn{3}{|c|}{$\begin{array}{l}\mathrm{HCl}, 0.2 \\
\text { per cent }\end{array}$} & \multicolumn{3}{|c|}{$\begin{array}{l}\mathrm{HCl}, 0.3 \\
\text { per cent }\end{array}$} & \multirow{2}{*}{ 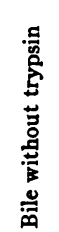 } & \multirow{2}{*}{ 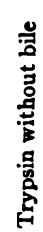 } \\
\hline & 芭 & 昜 & 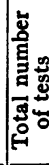 & 。 & 量 & 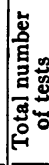 & 产 & 罾 & 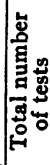 & 嵉 & 量 & 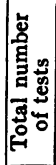 & 芦 & 炁 & 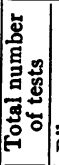 & 芦 & 密 & & \\
\hline 1 & + & + & 15 & 4 & 13 & & & & & & & & & & & & & 0 & 9 \\
\hline 2 & + & + & 6 & 4 & 5 & 4 & 0 & 3 & & & & & & & & & & 1 & 5 \\
\hline 3 & + & + & 14 & 14 & 14 & 4 & 3 & 4 & & & & & & & & & & 0 & 1 \\
\hline 4 & ${ }^{*}$ & * & 12 & 12 & 11 & & & & 6 & 1 & 2 & & & & & & & 1 & 1 \\
\hline 5 & + & + & 12 & 9 & 12 & 3 & 2 & 3 & 3 & 1 & 3 & 10 & 2 & 4 & & & & 0 & 8 \\
\hline 6 & - & + & 2 & 1 & 2 & & & & & & & & & & 4 & & 0 & 0 & 1 \\
\hline 7 & + & + & 13 & 7 & 12 & & & & 7 & 4 & 6 & 9 & 3 & 1 & & & & 2 & 6 \\
\hline 8 & + & + & 10 & 2 & 5 & & & & & & & & & & 9 & & 3 & 3 & 5 \\
\hline 9 & - & + & 3 & 0 & 3 & & & & & & & 2 & 0 & 2 & & & & 0 & 5 \\
\hline 10 & + & + & 5 & 4 & 5 & & & & & & & 2 & 2 & 1 & & & & 1 & 1 \\
\hline Total & 7 & 9 & 92 & 57 & 77 & 11 & 5 & 10 & 16 & 6 & 11 & 23 & 7 & 9 & 13 & & 3 & 8 & 42 \\
\hline
\end{tabular}

* Vomited, no secretion.

sphincter was at least partially open during almost the entire course of the experiment. (The possibility of its being open even when all tests were negative is not excluded.) It is to be noted that pancreatic juice (represented by trypsin) is present a much more considerable portion of the time than the other two secretions, bile and duodenal juice (as represented by sucrose).

In experiment 2 (fig. 2), 4 washings with water were followed by one with 0.09 per cent $(0.025 N) \mathrm{HCl}$, after which $250 \mathrm{cc}$. of the $\mathrm{HCl}$ were 


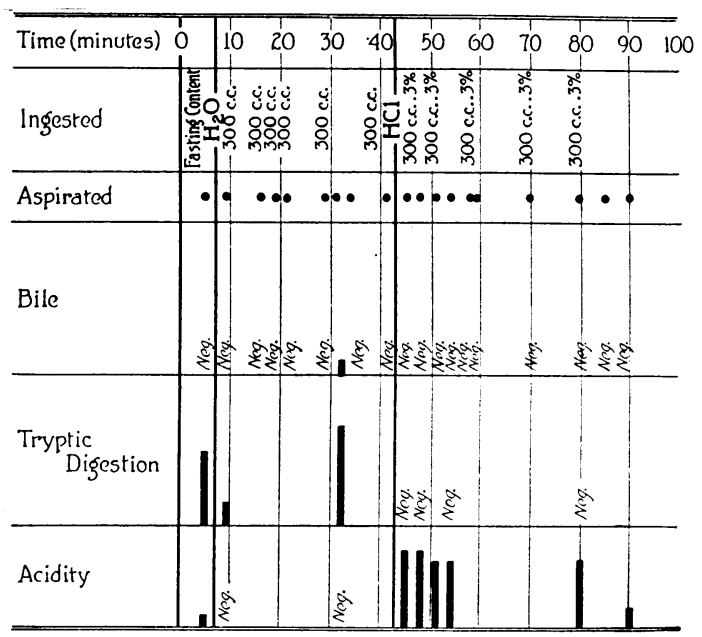

Fig. 6. (Experiment 6.) Shows the Presence in the Stomach of Trypsin DuRING Washings With Water; Its Disappearance DURING WASHINGS WITH 0.3 PER CENT ACID

Subject: Wm. W. Diagnosis: Pernicious anemia. Date: March 3, 1927.

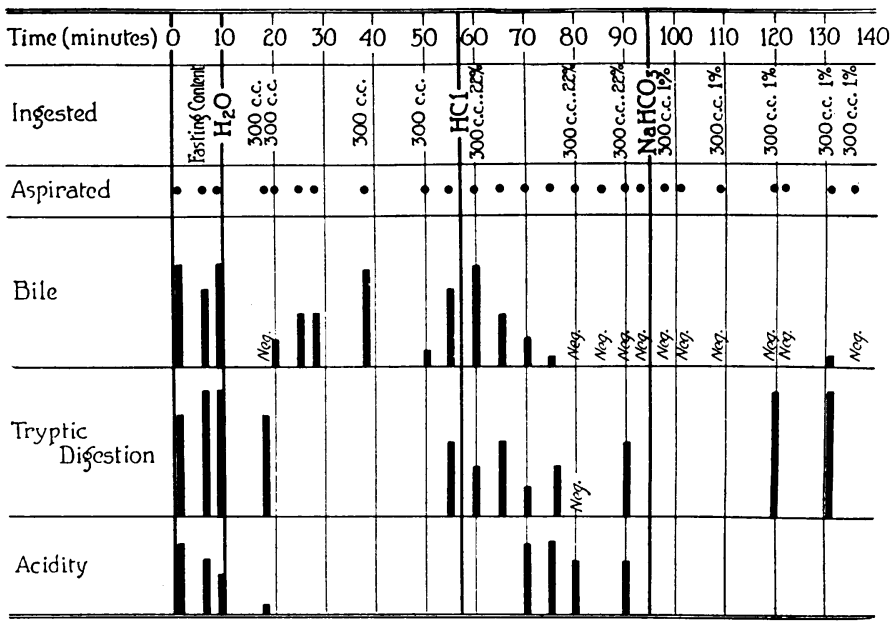

Fig. 7. (Experiment 11.) Shows the Decrease of Bile in the Stomach DURIng Washings with ACI, Trypsin Remaining UnChanged; Return of Bile and a Marked Increase of Trypsin on Washings with Alkali

Subject: Axel J. Diagnosis: Duodenal ulcer. Date: March 3, 1927. 
introduced and removed in 4 fractions. Two washings with water then followed. Trypsin was present during almost the entire procedure, but tended to decrease in amount during the administration of acid. Bile failed to appear during 2 of the washings with water and was lacking during the entire acid period. Both became strongly positive when washings with water were resumed.

In experiment 3 (fig. 3), on another case of pernicious anemia, bile and trypsin were present during 14 washings with $500 \mathrm{cc}$. of water each. Both decreased considerably in amount when dilute acid

TABLE 2

Regurgitation in miscellaneous cases. Shows the number of aspirations examined for both bile and trypsin and the number positive for each

\begin{tabular}{|c|c|c|c|c|c|c|c|c|c|c|c|c|c|c|c|c|c|c|c|}
\hline \multirow[b]{2}{*}{$\begin{array}{c}\text { Experi- } \\
\text { ment } \\
\text { number }\end{array}$} & \multicolumn{2}{|c|}{$\begin{array}{l}\text { Fasting } \\
\text { contents }\end{array}$} & \multicolumn{3}{|c|}{$\mathrm{H}_{2} \mathrm{O}$} & \multicolumn{3}{|c|}{$\begin{array}{l}\mathrm{NaHCO}_{3}, \\
1 \text { per cent }\end{array}$} & \multicolumn{3}{|c|}{$\begin{array}{c}\mathrm{HCl}, \\
0.14 \text { per cent }\end{array}$} & \multicolumn{3}{|c|}{$\underset{0.2 \text { per cent }}{\mathrm{HCl}}$} & \multicolumn{3}{|c|}{0.2 per cent } & \multirow{2}{*}{ 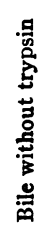 } & \multirow{2}{*}{ 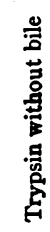 } \\
\hline & 芦 & 量 & 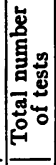 & 芦 & 禀 & 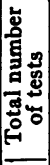 & 芦 & 㯰 & 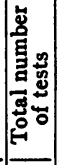 & 芦 & 量 & 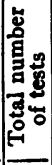 & 芦 & 量 & 岁 & مُ & 朂 & & \\
\hline 11 & + & + & 2 & 1 & 2 & 2 & 1 & . & & & & 6 & 4 & 5 & & & & 0 & 3 \\
\hline 12 & - & + & 7 & 2 & 5 & 6 & 3 & 4 & & & & & & & 3 & 0 & 1 & 0 & 5 \\
\hline 13 & + & + & 5 & 0 & 5 & 4 & 0 & 4 & & & & & & & 2 & 0 & 0 & 0 & 9 \\
\hline 14 & - & + & 2 & 0 & 2 & & & & & & & & & & 6 & 2 & 3 & 0 & 3 \\
\hline 15 & t & + & 10 & 1 & 6 & 5 & 0 & 5 & 9 & 3 & 5 & & & & & & & 3 & 15 \\
\hline 16 & - & + & 6 & 0 & 4 & & & & & & & & & & 2 & 0 & 0 & 0 & \\
\hline 17 & - & + & 2 & 0 & 1 & 3 & 0 & 3 & & & & & & & 5 & 1 & 2 & 0 & \\
\hline 18 & - & + & 3 & 0 & 2 & 5 & 0 & 0 & 2 & 0 & 0 & & & & & & & 0 & 2 \\
\hline 19 & + & + & 6 & 1 & 4 & 2 & 0 & 1 & & & & & & & 5 & 0 & 1 & & \\
\hline Total & 4 & 9 & 43 & 5 & 31 & 27 & 4 & 22 & 11 & 3 & 5 & 6 & 4 & 5 & 23 & 3 & 7 & 3 & 46 \\
\hline
\end{tabular}

$(0.09$ per cent $\mathrm{HCl})$ was introduced and increased as the acid was withdrawn. In experiment 4 (fig. 4), the findings are similar.

Experiment 5 (fig. 5) is also typical. Bile and trypsin were both present during washing with water and 0.09 per cent $\mathrm{HCl}$. During washing with 0.2 per cent $\mathrm{HCl}$ they disappeared completely and reappeared only intermittently and in minute amounts. Water was then introduced whereupon trypsin reappeared at once. Later on, bile also reappeared. The same results are shown even more strikingly in experiment 6 (fig. 6), where more concentrated acid was employed 
$(0.3$ per cent $\mathrm{HCl})$ and where tryptic activity was lacking entirely during the entire period of acid washing. Bile was positive only once, in one of the samples of washing with water.

The results of these cases together with four others, nos. 7 to 10 , are tabulated in table 1. In column 1 are recorded the numbers of the cases. In column 2 are shown the appearance or non-appearance of bile and trypsin in the fasting contents, and in the next five columns the numbers of washings with water and with solutions of $\mathrm{HCl}$, together

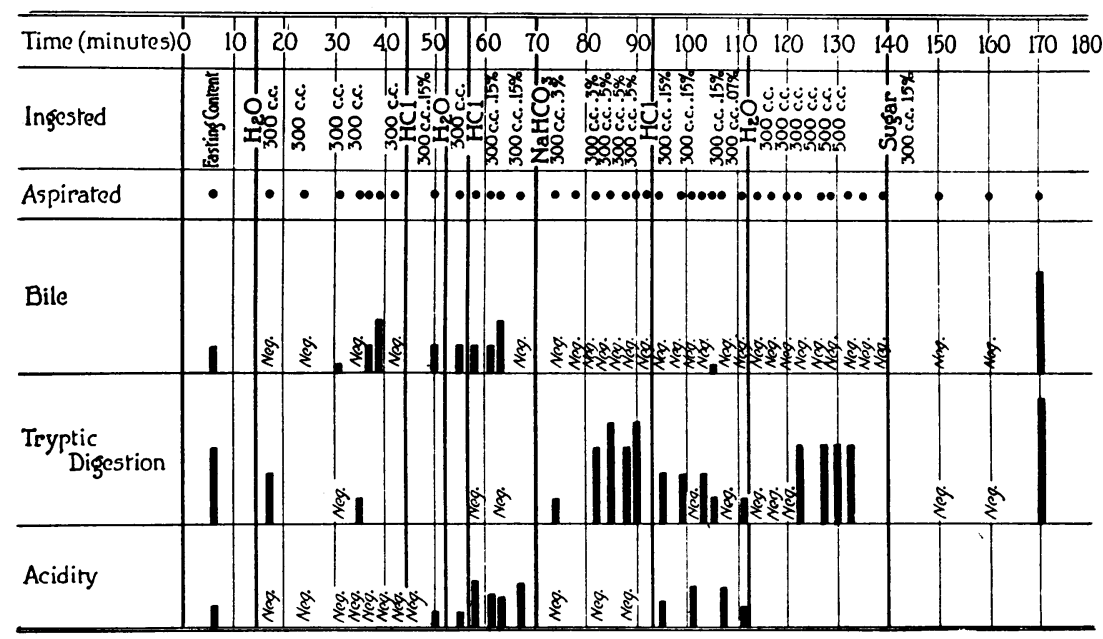

Fig. 8. (EXPERIMENT 15.) Shows the IndePENDENT Appearance in the STOMACH OF BILE AND TRYPSIN

Subject: Wm. C. Diagnosis: Retroperitoneal tumor. Date: February 17, 1927.

with the frequency of the appearance of bile and trypsin in the aspirated samples.

Case 11 (fig. 7 and table 2) was diagnosed as one of duodenal ulcer. Tryptic digestion was present during the entire time except in one acid washing but was somewhat decreased during the entire period of acid ingestion. Bile disappeared during the same period and failed to reappear except in traces after 30 minutes of washing with $\mathrm{NaHCO}_{3}$. The other cases (nos. 12 to 19), the findings from which are also tabulated in table 2, are of miscellaneous diagnoses other than pernicious anemia. 


\section{DISCUSSION}

\section{Independent appearance of bile and trypsin in the stomach}

One fact is brought out by these data, the frequency with which trypsin and bile appear independently. In the fasting contents, trypsin was present in all the cases examined, while in pernicious anemia (achylia) bile was present in 7 out of 9 cases or 78 per cent, and in the miscellaneous cases, it was present in 4 out of 9 or 44 per cent. In the last columns are shown the number of times in which trypsin occurred without bile and the number of times in which bile occurred without trypsin. As may be seen, while the latter occurrence is comparatively rare, the former happens with considerable frequency. In cases 13,16 and 18 , for instance, bile was absent during the entire experiment.

In much of the early work, bile was accepted as the only criterion of regurgitation. Hicks and Vischer (1915), for example, conclude, from the frequent absence of bile in the normal gastric contents, that "duodenal regurgitation is not the factor of greatest importance in the reduction of the high acidity of the stomach contents; for it is difficult to conceive of much pancreatic juice passing back through the duodenum without becoming mixed with bile." A number of other workers, however, have brought out the fact that pancreatic juice may appear independently in the stomach. Fowler, Rehfuss and Hawk (1915), for instance, found bile in 36 out of 67 cases tested (66.8 per cent) and trypsin in 34 out of 36 (or 94.4 per cent).

Baird, Campbell and Hearn (1924) failed to recognize this fact in discussing the neutralization of gastric acidity. They aspirated simultaneously from tubes in the stomach and duodenum. They found that when bile was flowing from the duodenal tube, none was obtained from the stomach, and they concluded that the neutralization of gastric acidity which occurred in these experiments must be due to the alkaline secretion of the mucous glands of the pylorus. There is, however, evidence of anatomical as well as of physiological nature, that bile and pancreatic juice may enter the duodenum separately.

As is well known, the pancreatic duct and the bile duct usually enter the duodenum through a common duct. Baldwin (1911), however, has shown that in 25 per cent of the cases investigated by him the ducts open separately. There is no evidence to show that the secretion from 
the gallbladder and the pancreas always flow at the same time, and it seems quite reasonable to assume that one might get gushes of bile containing very little or no pancreatic secretion. Further, Baldwin found that an accessory pancreatic duct (fig. 10), the duct of Santorini, which opens about three-fourths inch, to one inch, higher up than the common bile duct, was patent to injection in 77 per cent of the cases and patent to dissection in over 85 per cent of the cases that he examined. He found also that in some cases this accessory duct was large and apparently performed most of the work, in others it was smaller and sometimes was entirely functionless. It seems reasonable to suppose that pancreatic juice might flow to a varying extent through this duct even when the common duct is not functioning and when no bile is getting into the duodenum; and in the cases pictured by Baird, Campbell and Hearn, where a duodenal tube was placed at the level of the ampulla, and the bile removed by continuous aspiration, it may be that bile-free duodenal contents containing pancreatic juice was secreted into the duodenum through the assessory duct and was regurgitated into the stomach.

\section{Factors affecting the frequency of regurgitation}

a. Water. In tables 3 and 4 are listed the same experiments, together with the number of times regurgitation was observed, as judged by the presence of either bile or trypsin, and the number of times that regurgitation did not occur, as concluded from the fact that both tests were negative.

As has been brought out in the preceding paragraphs, regurgitation had occurred in all the fasting contents examined. In the washings which followed, regurgitation was found most frequently with the use of water, about the same number of times with sodium bicarbonate, and with decreasing frequency under the influence of acids of increasingly greater concentrations. This evidently is not in harmony with Boldyreff.

Previous workers have called attention to the frequency of regurgitation when water is used as a test meal. Rosemann (1907), for instance, in preparing animals with gastric fistulae for sham feeding, states, "Einmal gewann ich den Eindruck, als ob unter dem Einfluss dieser Spülung (mit distilliertem wasser), besonders leicht ein Zurück- 
treten galligen Darminhalts in den Magen stattfand." Ivy (1918), aspirating the stomach contents of dogs 15 minutes after the introduction of $400 \mathrm{cc}$. water, found that the portion aspirated was generally tinged with bile. Cathcart (1911), on the other hand, declared that water had no effect on regurgitation.

b. Acids and alkalis. In reviewing the literature on regurgitation in its relation to gastric acidity, one is struck with the wide divergence of

TABLE 3

Regurgitation in pernicious anemia. Shows the number of aspirations tested for both bile and trypsin, the number positive for one (indicating regurgitation), and the number negative for both (indicating no regurgitation)

\begin{tabular}{|c|c|c|c|c|c|c|c|c|c|c|c|c|c|c|c|c|}
\hline \multirow[b]{2}{*}{$\begin{array}{c}\text { Experiment } \\
\text { number }\end{array}$} & \multirow[b]{2}{*}{$\begin{array}{l}\text { Fasting } \\
\text { contents }\end{array}$} & \multicolumn{3}{|c|}{$\mathrm{H}_{2} \mathrm{O}$} & \multicolumn{3}{|c|}{$\begin{array}{l}\mathrm{HCl}, \\
0.09 \text { per cent }\end{array}$} & \multicolumn{3}{|c|}{$\begin{array}{c}\mathrm{HCl}, \\
0.14 \text { per cent }\end{array}$} & \multicolumn{3}{|c|}{$\begin{array}{c}\mathrm{HCl}, \\
0.2 \text { per cent }\end{array}$} & \multicolumn{3}{|c|}{$\begin{array}{c}\mathrm{HCl}, \\
0.3 \text { per cent }\end{array}$} \\
\hline & & 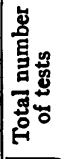 & $\begin{array}{l}+ \\
\text { 岁 } \\
\text { 息 } \\
\text { 学 }\end{array}$ & 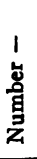 & 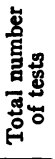 & 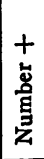 & 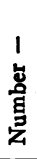 & 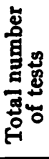 & 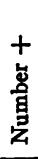 & 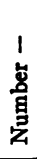 & 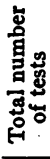 & + & 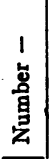 & 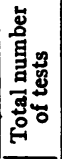 & 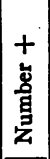 & 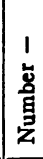 \\
\hline 1 & + & 15 & 13 & 2 & & & & & & & & & & & & \\
\hline 2 & + & 6 & 6 & 0 & 4 & 3 & 1 & & & & & & & & & \\
\hline 3 & + & 14 & 14 & 0 & 4 & 4 & 0 & & & & & & & & & \\
\hline 4 & & 12 & 12 & 0 & & & & 6 & 2 & 4 & & & & & & \\
\hline 5 & + & 12 & 12 & 0 & 3 & 3 & 0 & & & & 10 & 4 & 6 & & & \\
\hline 6 & + & 2 & 2 & 0 & & & & & & & & & & 4 & 0 & 4 \\
\hline 7 & + & 13 & 12 & 1 & & & & 7 & 6 & 1 & 9 & 1 & 8 & & & \\
\hline 8 & + & 10 & 6 & 4 & & & & & & & & & & 9 & 4 & 5 \\
\hline 9 & + & 3 & 3 & 0 & & & & & & & 2 & 2 & 0 & & & \\
\hline 10 & + & 5 & 5 & 0 & & & & & & & 4 & 4 & 0 & & & \\
\hline Total......... & 9 & 92 & 85 & 7 & 11 & 10 & 1 & 13 & 8 & 5 & 25 & 11 & 14 & 13 & 4 & 9 \\
\hline $\begin{array}{c}\text { Per cent of } \\
\text { total...... }\end{array}$ & 100 & & 92 & 8 & & 91 & 9 & & 62 & 38 & & 44 & 56 & & 31 & 69 \\
\hline
\end{tabular}

opinion held by various groups of workers. As was mentioned in the introduction to this paper, Boldyreff (1904) early conceived the idea that regurgitation is a normal process. He observed that regurgitation took place most readily when large quantities of fats or acids (dilute $\mathrm{HCl}$ ) had been ingested. $\mathrm{He}$ ascribed the effect of fats to their fatty acid components. Migai (1909) at Boldyreff's suggestion, investigated the question more fully. He found that a 0.5 per cent 
solution of $\mathrm{HCl}$ introduced into the stomach, lost about 75 per cent of its acidity after an hour, while a 0.3 per cent solution lost 44 per cent and a 0.1 per cent lost about 8 per cent in the same time.

On the basis of these and other similar observations Boldyreff (1911) elaborated a definite theory of duodenal regurgitation. He states that

TABLE 4

Regurgitation in miscellaneous cases. Shows the number of aspirations tested for both bile and trypsin, the number positive for one (indicating regurgitation) and the number negative for both (indicating no regurgitation)

\begin{tabular}{|c|c|c|c|c|c|c|c|c|c|c|c|c|c|c|c|c|}
\hline \multirow{2}{*}{$\begin{array}{c}\text { Experiment } \\
\text { number }\end{array}$} & \multirow[b]{2}{*}{ 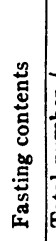 } & \multicolumn{2}{|c|}{$\mathrm{H}_{2} \mathrm{O}$} & \multicolumn{3}{|c|}{$\begin{array}{l}\mathrm{NaHCO}_{3} \text {, } \\
1 \text { per cent }\end{array}$} & \multicolumn{3}{|c|}{$\begin{array}{c}\mathrm{HCl}, 0.14 \\
\text { per cent }\end{array}$} & \multicolumn{3}{|c|}{$\begin{array}{l}\mathrm{HCl}, 0.2 \\
\text { per cent }\end{array}$} & \multicolumn{3}{|c|}{$\begin{array}{c}\mathrm{HCl}, \\
0.3 \text { per cent }\end{array}$} & \\
\hline & & 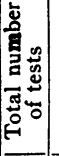 & 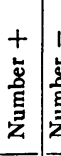 & 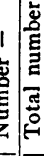 & $\frac{n}{0.0}$ & 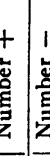 & 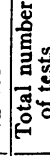 & 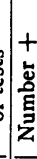 & \begin{tabular}{|c|}
1 \\
$\mathbf{5}$ \\
$\mathbf{5}$ \\
$\mathbf{z}$ \\
$\mathbf{z}$
\end{tabular} & 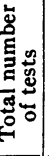 & $\begin{array}{c}+ \\
+ \\
\mathbf{d} \\
\mathbf{z} \\
\mathbf{z}\end{array}$ & & . & 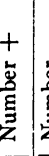 & & \\
\hline 11 & + & 2 & 2 & 0 & 2 & 2 & o & & & 6 & 5 & 1 & & & & Duodenal ulcer \\
\hline 12 & + & 7 & 5 & 2 & 6 & 5 & 1 | & & & & & & 3 & 1 & 2 & Duodenal ulcer \\
\hline 13 & + & 5 & 5 & 0 & 4 & 4 & 0 & & & & & & 2 & 0 & 2 & Duodenal ulcer \\
\hline 14 & + & 2 & 2 & 0 & & & & & & & & & 6 & 3 & 3 & Duodenal ulcer \\
\hline 15 & + & 10 & 7 & 3 & 5 & 5 & 0 & 95 & 4 & & & & & & & $\begin{array}{l}\text { Retroperitoneal } \\
\text { tumor }\end{array}$ \\
\hline 16 & + & 6 & 4 & 2 & & & & & & & & & 2 & 0 & 2 & Asthma \\
\hline 17 & + & 2 & 1 & 1 & 3 & & 1 & & & & & & 5 & 2 & 3 & $\begin{array}{c}\text { Compression } \\
\text { myelitis }\end{array}$ \\
\hline 18 & + & 3 & 2 & 1 & 5 & 0 & 5 & 22 & 0 & & & & & & & Normal \\
\hline 19 & + & 6 & 4 & 2 & 2 & 1 & 1 & & & & & & 5 & & 4 & Simple achylia \\
\hline Total... & 9 & 43 & \begin{tabular}{l|l}
32 & 1
\end{tabular} & 11 & 27 & 19 & $\begin{array}{ll}8 & 1 \\
\end{array}$ & 1 & 4 & & 5 & $1 \mid 2$. & & & 16 & \\
\hline $\begin{array}{r}\text { Per cent of } \\
\text { total....... }\end{array}$ & 100 & & & & & 703 & & 6 & 36 & & & 17 & & & 70 & \\
\hline 23 & $*$ & 9 & 9 & 0 & 4 & 4 & 0 & & & & & & 6 & 6 & 0 & Polya's operation \\
\hline $\begin{array}{c}\text { Per cent of } \\
\text { total....... }\end{array}$ & & & 100 & 0 & & 00 & 0 & & & & & & & 100 & 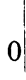 & \\
\hline
\end{tabular}

* Not tested.

when the gastric content is too acid, or the acid is present in the stomach in too large amounts, the alkaline intestinal juice (especially the pancreatic juice) comes in and neutralizes it. The same thing may happen when no acid is introduced, but only gastric juice is present, since the juice as secreted has a much higher acidity $(0.5$ per cent $\mathrm{HCl})$ 
than the level at which it normally is found in the fasting stomach $(0.15$ to 0.2 per cent $\mathrm{HCl})$. When the normal function of the pancreas is disturbed one of two conditions results,- - "hyperacidity," failure of regurgitation and hence of neutralization, or "hypersecretion," regurgitation of pancreatic juice in excess of the optimum amount, resulting in accumulation of a large amount of gastric contents of low acidity. He believed that when neutral or alkaline food is introduced, gastric juice is secreted until the optimum acidity is attained. He calls these processes the "self-regulation of the acidity of the gastric contents." Spencer, Rehfuss and collaborators (1916) subscribed to these views, as well as Bennett and Ryle (1921) and others working at Guy's Hospital, London.

Morse (1916) attacked the problem in a different way. He introduced water and acids of different concentrations in measured amounts into the stomachs of dogs and withdrew them after 30 minutes. If the amount was increased, he inferred that regurgitation had taken place, and if it was decreased, he concluded that some had been discharged through the pylorus. He found that when water was ingested, part of it was always discharged during the thirty minute period, but when 0.5 per cent $\mathrm{HCl}$ was given none was expelled through the pylorus, and regurgitation in 9 out of 12 cases had taken place. When acid of lower concentration was introduced sometimes regurgitation and sometimes discharge of the acid occurred.

Ehrmann and Lederer (1909) on the other hand, found that trypsin was usually present in an Ewald test meal aspirated after 45 minutes, but if acid was given with the meal the trypsin content generally was low and in no case was there an increase. They did not consider the possibility that regurgitation may have been decreased and they suggested that acid had had a destructive effect upon the ferment.

Ehrenreich (1912) does not think the question of regurgitation so simple as Boldyreff suggests, as he finds no general rule for its appearance. He finds trypsin present with sufficient frequency for him to decide that it is resistant to the action of $\mathrm{HCl}$ at least during the period of his experiments. He presents data on fractional test meals with three groups of patients, (a), achlorhydria, trypsin in 4 out of 6 cases; (b), hypochlorhydria, trypsin present in 3 out of 5 cases, and $(c)$ normal and hyperchlorhydria, trypsin present in 10 out of 24 cases 
and doubtful in 4. According to these figures, regurgitation sometimes accompanies high acidity and sometimes is lacking. On the other hand, it may be present or absent in cases of achlorhydria.

Hicks and Vischer (1915) got regurgitation in 6 out of 30 trials when $150 \mathrm{cc} .0 .5$ per cent $\mathrm{HCl}$ was left in a dog's stomach for 15 minutes and in 15 out of 36 trials when left for 30 minutes. When $100 \mathrm{cc}$. of acid of lower concentration, i.e., 0.4 per cent $\mathrm{HCl}$, was left in the stomach for 20 minutes, no regurgitation occurred in 100 per cent of 10 cases.

In our own experiments we did not obtain conclusive results from the use of acid as concentrated as 0.5 per cent $\mathrm{HCl}$, as the patients usually either vomited or felt definite symptoms of gagging, which was invariably accompanied by the passage of bile and pancreatic juice in large amounts through the pylorus. We therefore used 0.3 per cent $\mathrm{HCl}$ in most of our cases and found that unless large amounts were introduced, gagging seldom occurred. In the pernicious anemia cases, the tolerance to acids was especially low, and in one instance even 0.09 per cent $\mathrm{HCl}$ could not be used.

As stated above, regurgitation occurrred less frequently when acid was introduced, than when water or alkali. In the pernicious anemia cases (table 3), regurgitation occurred in 100 per cent of the fasting contents, in 92 per cent of the water washings, 91 per cent of the 0.09 per cent $\mathrm{HCl}$ samples, and 62 per cent, 44 per cent and 31 per cent with 0.14 per cent, 0.2 per cent and 0.3 per cent $\mathrm{HCl}$ solutions respectively. The records for the miscellaneous cases (table 4) are not dissimilar, except that the frequency of regurgitation in the presence of water is somewhat less, (74 per cent), indicating that the atonic sphincter of pernicious anemia reacts to the slight stimulus of water less readily than does the normal.

The discrepancy between our results and Morse's may possibly be explained in another way. As will be recalled, he found greater regurgitation with higher concentrations of acids. Morse examined his aspirated solutions for bile but not for pancreatic juice. He judged regurgitation in the absence of bile solely by measuring the relative amounts of gastric content recovered after one-half hour. He apparently does not consider the different rates at which water and acids are normally discharged from the stomach. It has been shown by Ivy (1918) that water in both man and dogs begins to leave the stom- 
ach very soon after ingestion: in man the emptying time usually varies from 400 to $100 \mathrm{cc}$. in fifteen minutes; in dogs, water begins to leave the stomach practically as soon as it reaches it,-i.e., 5 to 10 seconds after drinking and has an emptying time of 30 minutes to 1 hour. Ivy states that water recovered at the end of 15 minutes is usually tinged with bile. Morse records such slight loss of fluid in his 30 minute periods, that it seems possible both discharge and regurgitation of pancreatic juice may have occurred in his tests with water and dilute $\mathrm{HCl}$. Our own experiments show that with washings of water, the ratio of trypsin to bile was considerably greater than with washings of acid, and regurgitation if judged solely by the characteristic color of bile, would have been unobserved.

\section{THE RÔLE PLAYED BY THE PYLORUS}

This decrease in the tendency of regurgitation to occur in the presence of acid may be due either to a direct effect on the pyloric sphincter or to an inhibition of the secretion of either bile or pancreatic juice, or both.

That the secretion of bile and pancreatic juice is stimulated, rather than inhibited by acids, is well known. This fact was early brought out by Bayliss and Starling (1902) and confirmed by Pavloff (1910). They found the secretion decreased by alkalis. Cole (1925) measured the tonicity of the sphincter of Oddi by means of a cannula, when various fluids were introduced into the stomach and found that when the stomach was empty the sphincter would withstand a pressure of 40 to $100 \mathrm{~mm}$. of water, that there was a slight increase in the tonicity when 0.5 per cent $\mathrm{NaOH}$ was in the stomach and a marked decrease when 0.5 per cent $\mathrm{HCl}$ was introduced. This would imply that the effect was initially produced through the gastric mucosa which is not in accordance with the results obtained by the investigators mentioned above. Archibald (quoted by Mann, 1924) found that acid applied to the sphincter increased the tonus.

Some light may be thrown upon the mechanism by which the decrease of regurgitation with ingestion of acid is brought about, by a consideration of experiment 23 (table 4 and fig. 9). This patient had undergone Polya resection, an operation in which the entire pylorus as well as the pyloric sphincter is removed. As may be seen from 


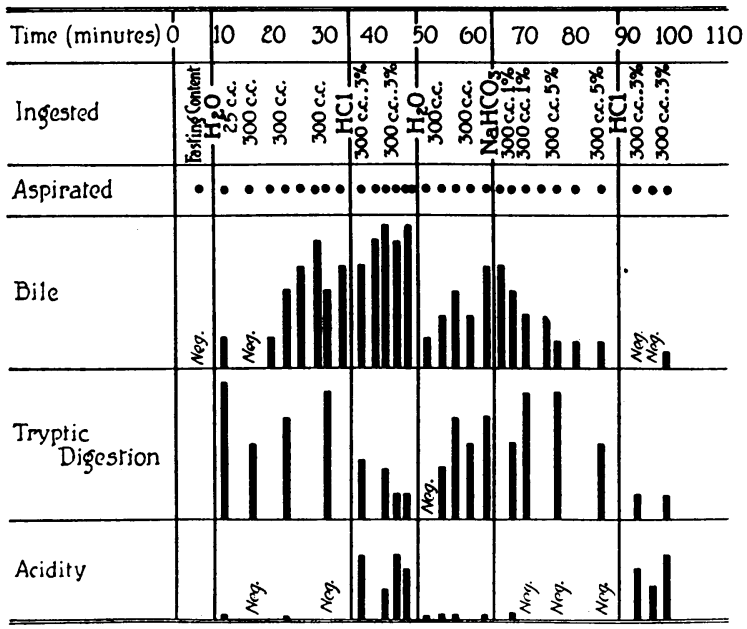

Fig. 9. (Experiment 23.) Shows the Constant Presence in the Stomach of Duodenal Content after Gastroenterostomy

Subject: Chas. C. Diagnosis: Polya's operation for pyloric carcinoma. Date: April 16, 1927.

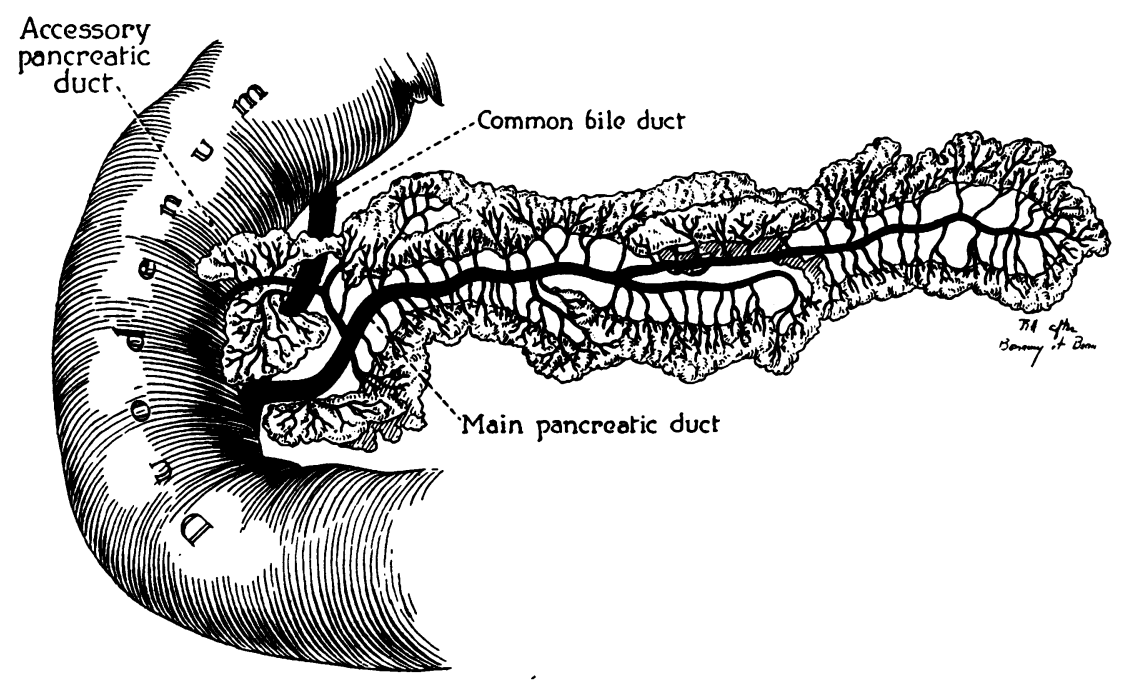

Fig. 10. Usual Relation of Common Bine Duct and Pancreatic Ducts 
the chart, tryptic digestion was secured from all but one of the samples recovered and bile was usually present, while no sample was negative for both.

This experiment seems to indicate that under the conditions of these experiments bile and trypsin are present in the duodenum a considerable portion of the time, but are prevented from finding entrance for brief periods during which the pylorus is closed.

Hicks and Vischer (1915) showed that regurgitation in the cat is effected by rhythmical pulsations and segmentation movements of the upper duodenum. During these moments of contraction, the pressure in the duodenum may conceivably rise higher than in the pars pylorica and the duodenal contents be forced into the stomach only to be withdrawn when relaxation of the duodenum occurs. Ryle (1926) discusses this possibility at length, and speaks of its as a "to and fro" mechanism. Any stimulus that may increase the tone of the gastric musculature including the pyloric sphincter would tend to decrease the amount and frequency of regurgitation. That such an increase of tone may be brought about by acid in the duodenum is not out of harmony with our results. Carlson (1924) has shown that usually the pylorus is in a state of moderate tonus, with periodic variations which may oscillate between states of extreme spasm and states of complete relaxation and quiescence; and that mechanical or chemical stimuli (water, $\mathrm{HCl}, \mathrm{Na}_{2} \mathrm{CO}_{3}$ ) or irritation of the duodenal mucosa may bring about contractions of the pylorus.

\section{CONCLUSIONS}

This, then, seems to us to be a possible exposition of the mechanism of regurgitation. That the pylorus, for the most part, is in a state of slight tonus and in achylia it is in marked relaxation, except when stimulated to close; that, as a result of periodic characteristic movements of the upper duodenum, such as were described by Hicks and Vischer (1915), bile and pancreatic juice is being forced into the stomach at moments when the pressure in the duodenum rises above that in the stomach, and may pass back into the upper duoduenum as a period of relaxation there follows; that water and $\mathrm{NaHCO}_{3}$ may exert some slight tonic effect on the pylorus (possibly acting through the duodenal mucosa) and $\mathrm{HCl}$, up to concentrations of about 0.3 per cent increases 
this tonus still more. Large amounts $(250$ to $400 \mathrm{cc}$.) of $\mathrm{HCl}$ of higher concentrations, 0.4 to 0.5 per cent, especially in the case of pernicious anemia patients, affects a different mechanism, the vomiting reflex or possibly merely gagging.

TABLE 5

Regurgitation with fractional test meals

\begin{tabular}{|c|c|c|c|c|c|c|c|c|c|c|c|c|c|}
\hline \multirow{2}{*}{ 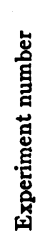 } & \multirow[b]{2}{*}{ Diagnosis } & \multicolumn{2}{|c|}{$\begin{array}{l}\text { Fasting } \\
\text { content }\end{array}$} & \multicolumn{3}{|c|}{$\mathrm{H}_{2} \mathrm{O}$} & & \multicolumn{5}{|c|}{ Fraction } & \multirow[b]{2}{*}{ Nature of mea } \\
\hline & & 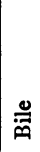 & 虽 & 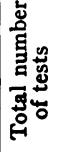 & $\begin{array}{l}+ \\
\text { + } \\
\text { 狊 } \\
\text { 它 }\end{array}$ & I & & 1 & 2 & 3 & \begin{tabular}{l|l}
4 & 5
\end{tabular} & 6 & \\
\hline 14 & Duodenal ulcer & - & + & 7 & 5 & 2 & $\begin{array}{l}\text { Bile } \\
\text { Trypsin }\end{array}$ & - & $\begin{array}{l}+ \\
+\end{array}$ & $\begin{array}{l}+ \\
+\end{array}$ & $\begin{array}{l}+ \\
+\end{array}$ & & Cane sugar \\
\hline 15 & $\begin{array}{l}\text { Retroperitoneal } \\
\text { tumor }\end{array}$ & + & + & 10 & 7 & 3 & $\begin{array}{l}\text { Bile } \\
\text { Trypsin }\end{array}$ & - & - & $\begin{array}{l}+ \\
+\end{array}$ & & & Glucose \\
\hline 16 & Asthma & - & + & 6 & 4 & 2 & $\begin{array}{l}\text { Bile } \\
\text { Trypsin }\end{array}$ & - & + & - & - & - & Albumin \\
\hline 17 & $\begin{array}{l}\text { Compression } \\
\text { myelitis }\end{array}$ & - & + & 2 & 1 & 1 & $\begin{array}{l}\text { Bile } \\
\text { Trypsin }\end{array}$ & - & + & - & - & - & Glucose \\
\hline 18 & Normal & - & + & 3 & 2 & 1 & $\begin{array}{l}\text { Bile } \\
\text { Trypsin }\end{array}$ & - & - & - & -- & -1 & Glucose \\
\hline 19 & Simple achylia & + & + & 11 & 9 & 2 & $\begin{array}{l}\text { Bile } \\
\text { Trypsin }\end{array}$ & - & + & + & +- & - & Glucose \\
\hline 20 & Simple achylia & + & + & 6 & 4 & 2 & $\begin{array}{l}\text { Bile } \\
\text { Trypsin }\end{array}$ & - & - & - & - & - & Albumin \\
\hline 21 & Pyloric obstruction & + & + & 2 & 2 & 0 & $\begin{array}{l}\text { Bile } \\
\text { Trypsin }\end{array}$ & - & - & + & & & Gruel \\
\hline 22 & Pernicious anemia & + & + & 6 & 6 . & 0 & $\begin{array}{l}\text { Bile } \\
\text { Trypsin }\end{array}$ & - & - & - & - & & Gruel \\
\hline
\end{tabular}

These views are supported by our findings with fractional test meals. In table 5 are recorded the data from 9 such experiments, either with solutions of sugar or albumin or gruel. 
As may be seen, regurgitation of either bile or trypsin occurred in 100 per cent of the cases; in two of them both bile and trypsin were present; in one of the others, bile appeared without trypsin, and in the remainder, trypsin without bile.

It may be noted that regurgitation tended to occur in the last fractions removed as the stomach became emptied. This same phenomenon was observed occasionally in the previous experiments and has been mentioned frequently by other workers (i.e., Ryle, 1926, p. 47 , and Ivy, 1918).

This tendency for duodenal regurgitation to take place when the stomach is empty, supports the interpretation, offered by Berglund, Wahlquist, and Sherwood (1927), of the discrepancies between the titration curves of total chlorides and of free acid secreted under the action of histamine.

\section{SUMMARY}

Regurgitation into the stomach when fasting, as well as when water and dilute solutions of $\mathrm{HCl}(0.09,0.14,0.2$ and 0.3 per cent $)$ and 1 per cent solutions of $\mathrm{NaHCO}_{3}$ were introduced has been investigated. Test meals of pure solutions and of gruel were also employed.

The following results were found:

Regurgitation of duodenal contents into the fasting stomach occurs with great frequency (100 per cent of our own cases). It may occur in the presence of a test meal, or of any of the reagents mentioned above.

Water and 1 per cent $\mathrm{NaHCO}_{3}$ have a slight inhibiting effect in the normal stomach, and a much less effect in the atonic stomach of pernicious anemia.

$\mathrm{HCl}(0.09$ per cent $)$ inhibits regurgitation somewhat more than water and $\mathrm{NaHCO}_{3}$ while more concentrated acids (up to 0.3 per cent $\mathrm{HCl}$ ) decreased it in our cases to about 30 per cent.

Regurgitation takes place with special frequency as the stomach becomes emptied, regatdless of the type of meal employed.

The regurgitated material may include bile, pancreatic juice (trypsin) and secretion of the duodenal mucosa (sucrase). These may occur together, or any one may occur independently. Bile is regurgitated rarely without trypsin, and trypsin much more frequently without bile. The ratio of bile to trypsin increases in the presence of acid. 


\section{BIBLIOGRAPHY}

Archibald, E., Surg., Gynec. Obstet., 1919, xxviii, 529. The Experimental Production of Pancreatitis in Animals as the Result of the Resistance of the Common Duct Sphincter.

Baird, M. McC., Campbell, J. N. H., and Hern, J. R. B., Guy's Hosp. Reports, 1924, lxxiv, 23. The Importance of Estimating Chlorides in the Fractional Test Meal Samples, and Some Experiments with the Duodenal Tube.

Baldwin, W. M., Anat. Record, 1911, v, 197. The Pancreatic Ducts in Man, Together with a Study of the Microscopical Structure of the Minor Duodenal Papilla.

Bayliss, W. M., and Starling, E. H., J. Physiol., 1902, xxviii, 325. The Mechanism of Pancreatic Secretion.

Bayliss, W. M., Principles of General Physiology. London, 1924, 4th ed.

Beaumont, W., Physiology of Digestion. Edinburgh, 1838.

Bennett, T. I., and Ryle, J. A., Guy's Hosp. Reports, 1921, 1xxi, 286. Studies in Gastric Secretion. V. A Study of Normal Gastric Function Based on the Investigation of One Hundred Healthy Men by Means of the Fractional Method of Gastric Analysis.

Berglund, Hilding, Wahlquist, H., and Sherwood, K. K., Proc. Soc. Exper. Biol. and Med., 1927, xxiv, 927. Hydrochloric Acid and Total Chlorine Content of Pure Gastric Juice Produced after Histamine Injection.

Boldyreff, W., Arch. de Sciences Biologiq. St. Petersburg, 19.04, ix, (Quoted from Pavloff).

Boldyreff, W., Ergebn. d. Physiol., 1911, xi, 121. Einige neue Seiten der Tätigkeit des Pankreas.

Carlson, A. J. and Litt., S., Arch. Int. Med., 1924, xxxiii, 281. Studies on the Visceral Nervous System. On the Reflex Control of the Pylorus.

Cathcart, E. P., J. Physiol., 1911, xlii, 433. Reflux from Intestine to Stomach.

Cole, W. H., Am. J. Physiol., 1925, lxxii, 39. Relation of Gastric Content to the Physiology of the Common Duct Sphincter.

Ehrenreich, M., Ztschr. f. klin. Med., 1912, lxxv, 231. Ueber die kontinuierliche Untersuchung des Verdauungs-ablauf mittels der Magenverweilsonde.

Ehrmann, R., and Lederer, R., Klin. Wchnschr., 1909, xlv, 1450. Ueber die Wirkung der Salzsäure auf die Fermentsekretion des Magens und der Bauchspeicheldrüse.

Folin, Otto, Laboratory Manual of Biological Chemistry, New York, 1925.

Fowler, C. C., Rehfuss, M. E., and Hawk, P. B., J. Am. Med. Assoc., 1915, lxv, 1021. Gastro-intestinal Studies. X. An Investigation of the Gastric Residuum in Over One Hundred Normal Cases.

Hicks, C. J., and Visher, J. W., Am. J. Physiol., 1915, xxxix, 1. Contributions to the Physiology of the Stomach. XXVII. The Mechanism of Regurgitation of the Stomach.

Ivy, A. C., Am. J. Physiol., 1918, xlvi, 420. Contributions to the Physiology of the Stomach. XIVIII. Studies in Water Drinking. 
Migai, Diss. St. Petersburg, Quoted from W. M. Bayliss, 1909, 371, 4th ed. London, 1924.

Morse, W. E., Am. J. Physiol., 1916, xli, 439. The Relation of Acid to Gastric Discharge and Duodenal Regurgitation in the Dog.

Pavloff, I. P., The Work of the Digestive Glands. (Translated by Thompson.) London, 1910, 2nd ed.

Rosemann, E., Arch. f. d. ges. Physiol., 1907, cxviii, 467. Beiträge zur Physiologie der Verdauung. I. Die Eigenschaften und die Zusammensetzung des durch Scheinfütterung gewonnenen Hundemagensaftes.

Ryle, J. A., Gastric Function in Health and Disease, Oxford University Press, 1926.

Schittenhelm, Münch. med. Wchnschr., 1908, lv, 1459. Ueber Fälle von Rückfluss des Pankreassaftes in den Magen.

Spencer, W. H., Meyer, G. P., Rehfuss, M. E., and Hawk, P. B., Am. J. Physiol., 1916, xxxix, 459. Gastro-intestinal Studies. XII. Direct Evidence of Duodenal Regurgitation and Its Influence upon the Chemistry and Function of the Normal Human Stomach. 